\title{
The Urgent Need for the Use of Pre-Exposure Prophylaxis (PrEP) in the Prevention of HIV/AIDS in Sub-Saharan Africa
}

1 Israel Oluwasegun Ayenigbara

1 Department of Human Kinetics and Health Education, Univerity of Ibadan, Ibadan, Nigeria

\section{Abstract}

Human immunodeficiency virus (HIV) is an infection that came into existence decades back; it spread across the African countries in the late 1970s, and is currently endemic across the world. HIV is a major public health problem all over the world, as it has claimed more than 35 million lives. There were around 36.9 million individuals living with HIV at the end of 2017, and Sub-Saharan Africa remains the most affected by HIV infection with 1 in 25 adults (4.1\%) living with the virus, accounting for $70 \%$ of the people living with HIV worldwide. Unfortunately, Sub-Saharan Africa continues to be the continent with the highest cases of infections and deaths from HIV/AIDS even after the implementation of various HIV/AIDS prevention methods. Fortunately, pre-exposure prophylaxis (PrEP) offers the world a novel way of curtailing the HIV/AIDS epidemic, as PrEP is highly effective for preventing HIV if it is used as prescribed. This paper discusses the urgent need for the use of PrEP in the prevention of HIV/AIDS in Sub-Saharan Africa. It is a review paper in which the meaning of PrEP was discussed, people who need PrEP were identified, the rationale for the use of PrEP for the prevention of HIV/AIDS in Sub-Saharan Africa were highlighted, and probable obstacles to the successful implementation of PrEP for the prevention of HIV/AIDS in Sub-Saharan Africa were also identified. It was concluded that to achieve the 90-90-90 goals set by UNAIDS to help end the AIDS epidemic in the world, PrEP offers a new and novel way for HIV prevention, and its implementation across all African countries is urgently needed for the prevention of HIV/AIDS in Sub-Saharan Africa.

Keywords: HIV/AIDS, pre-exposure prophylaxis (PrEP), SubSaharan Africa, prevention

Article received: 8.4.2019.

Article accepted: 1.9.2019.

DOI: $10.24141 / 1 / 5 / 2 / 5$

\section{Corresponding author:} Israel Oluwasegun Ayenigbara A: University of Ibadan, Ibadan, Nigeria

E-mail: Histrealite2647@gmail.com

T: +234 8139177538 


\section{Key points}

1. PrEP is for people without HIV, but who are at a very high risk of getting it from sex, injections and drug use, for example, sex workers, people who inject drugs (PWID), men who have sex with men (MSM), prisoners, women and girls, transgender people, children, young people and adolescents, and people with disabilities.

2. Sub-Saharan Africa remains the most affected by HIV infection with 1 in 25 adults (4.1\%) living with the virus, accounting for $70 \%$ of the people living with HIV worldwide (2).

3. PrEP is highly effective for preventing HIV if it is used as prescribed, as daily PrEP reduces the risk of getting HIV from sex by more than $90 \%$, among people who inject drugs, it reduces the risk by more than $70 \%$, and the risk of getting HIV from sex will be lower if PrEP is combined with condoms and other prevention methods (3).

4. To achieve the 90-90-90 goals set by UNAIDS, the number of new HIV infections should decrease to approximately 500,000 before 2020 , and one of the major factors for achieving this goal is the use of PrEP all over the world.

\section{Introduction}

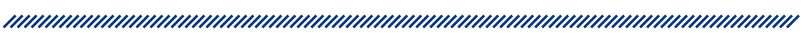

Human immunodeficiency virus infection and acquired immune deficiency syndrome (HIV/AIDS) is a range of conditions caused by an infection with the human immunodeficiency virus (HIV) (1). Importantly, HIV is an infection that came into existence decades back from a virus that infected chimpanzees; it spread across the African countries in the late 1970s, and is currently endemic around the world, with the highest occurrence in Africa. HIV causes ailment because it destroys the basic immune system cells in the body, and after a long period of time, the HIV virus overpowers it. After the initial infection, one may not have any side effects or may experience flu like disease for a short period of time. HIV continues to be a major public health problem across the world, having claimed over of 35 million lives (2).
For instance, in 2017, 940000 people died from HIVrelated causes worldwide; also, there were around 36.9 million people living with HIV towards the end of 2017, with 1.8 million people newly infected in 2017 worldwide. Unfortunately, Africa is the most affected continent with the HIV infection epidemic. With 25.7 million people living with HIV in 2017, the African continent likewise represents more than $66 \%$ of the worldwide aggregate of new HIV infections cases (2). The aforementioned statistics about HIV/AIDS is disturbing. Although, on the positive side, between the year 2000 and 2017, new HIV infections were reduced by $36 \%$, and HIV-related deaths diminished by $38 \%$, with 11.4 million lives spared because of the antiretroviral therapy (ART). However, the most disturbing is that sub Saharan African countries still recorded and continues to record the highest number of HIV infection and deaths from HIV/ AIDS. With the hope to help in reducing the number of HIV infections in Sub-Saharan Africa countries, this review looked at the urgent need for the use of pre-exposure prophylaxis (PrEP) for the prevention of HIV/AIDS in Sub-Saharan African countries.

\section{Sources of Information}

Literature was retrieved in Web of Science, Google and Spring Link databases. Furthermore, major international and national health sites, for example, the World Health Organization, Centers for disease control and prevention were searched to obtain related information. Year of production of Journals was not a factor as the researcher needed to get all available data on PrEP. Careful screening was done to ensure that significant data was incorporated into this review. Subsequently, the articles included in this review were limited just to those written in English. 


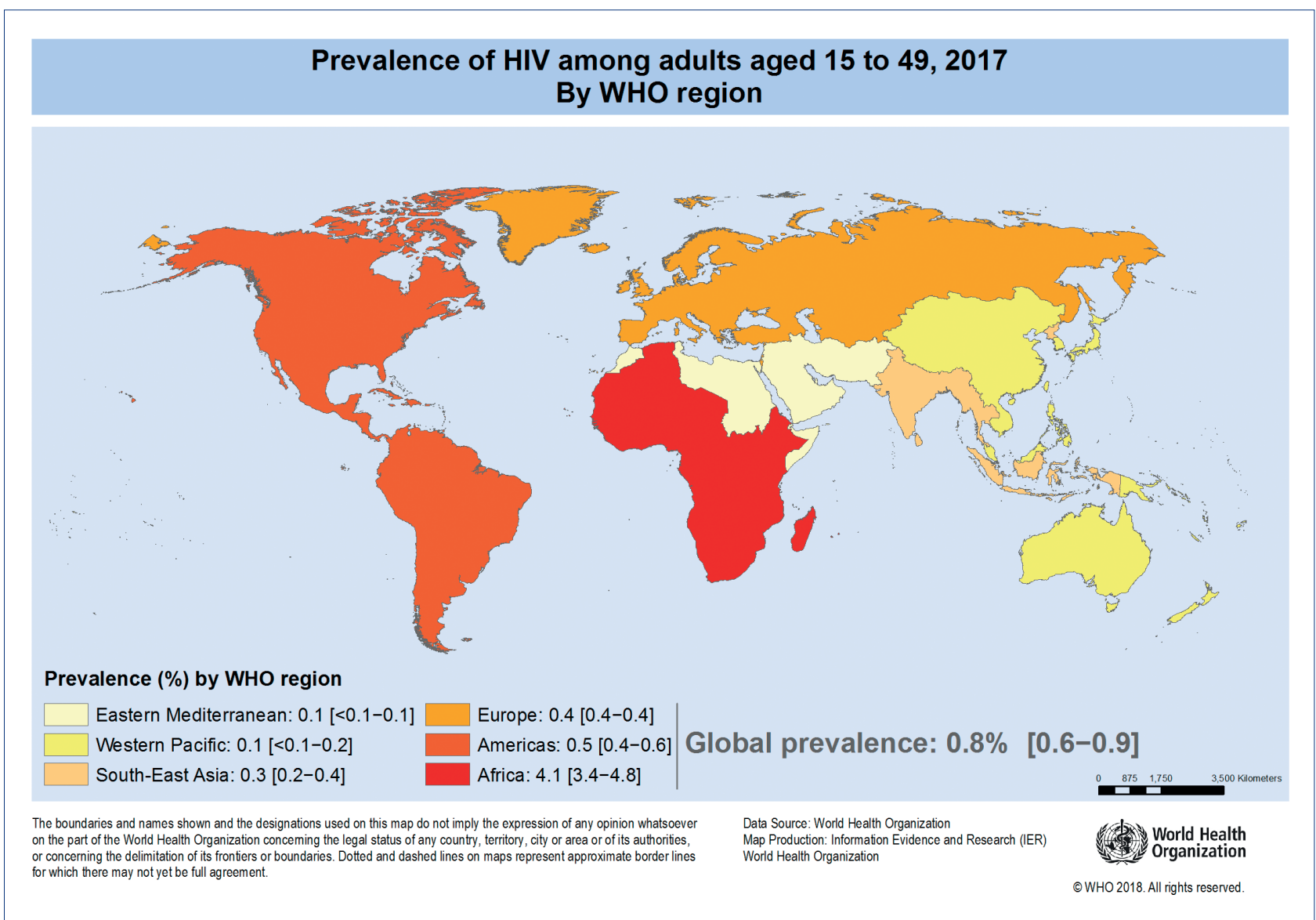

Figure 1. Sub-Saharan Africa remains most affected by HIV infection with 1 in 25 adults (4.1\%) living with the virus, accounting for $70 \%$ of the people living with HIV worldwide. (2)

\section{Review on the need for the use of pre-exposure prophylaxis (PrEP) in the prevention of HIV/AIDS in Sub-Saharan Africa}

\subsection{What is pre-exposure prophylaxis (PrEP)}

Pre-exposure prophylaxis (PrEP) is a term used when people at a very high risk of HIV take HIV medicines daily to reduce their chances of getting infected with the deadly virus. Importantly, PrEP can stop HIV from taking hold and spreading throughout the body of an individual (3). Furthermore, PrEP is highly effective for preventing HIV if used as prescribed, but it is much less effective when not taken consistently or regularly. A combination of two HIV medicines (tenofovir and emtricitabine), sold under the name Truvada ${ }^{\circledR}$, is approved for daily use as PrEP to help prevent an HIV-negative person from getting HIV from a sexual or injection-drugusing partner who is positive $(3,4)$.

Multiple studies have affirmed that PrEP is highly effective for preventing HIV if it is used as prescribed, but PrEP is much less effective when it is not taken consistently as required. Significantly, daily PrEP reduces the risk of getting infected with HIV from sex by more than $90 \%$, among people who inject drugs, it reduces the risk of HIV infection by more than $70 \%$, and the risk of getting HIV from sex will be lower if PrEP is combined with condoms and other HIV prevention methods (3). 


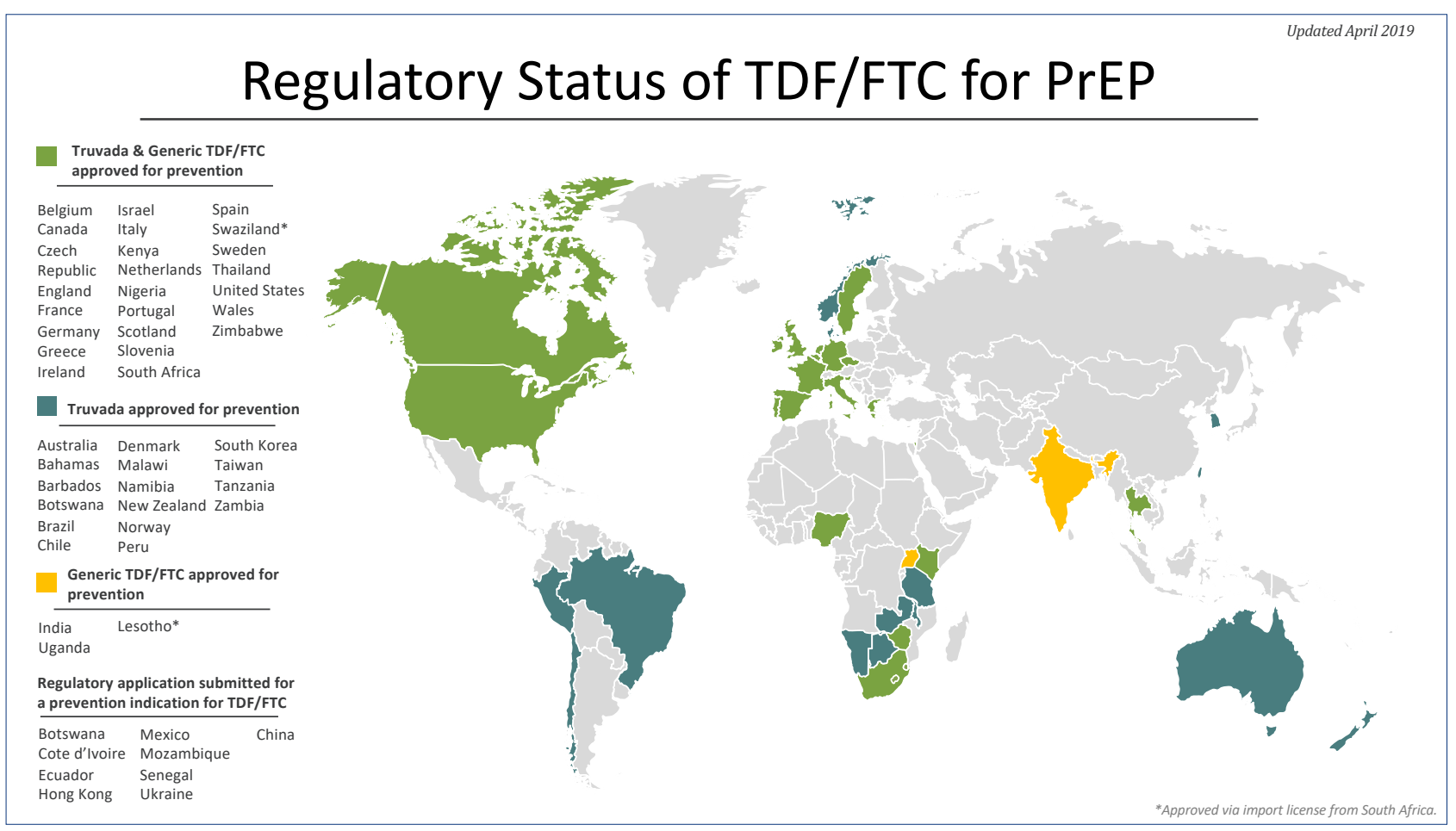

Figure 2. Regulatory Status of TDF/FTC for pre-exposure prophylaxis (PrEP)

Picture Source: AVAC: Global Advocacy for HIV Prevention (2018).

\subsection{Who needs pre-exposure prophylaxis (PrEP)}

For those at a very high risk of HIV infection, for example: sex workers, people who injects drugs (PWID), men who have sex with men (MSM), prisoners, women and girls, transgender people, children, young people and adolescents, and people with disabilities, PrEP can significantly reduce their risk of HIV infection if taken daily and consistently as required $(3,5)$.

Notably, vaccines and PrEP are different; a vaccine modifies and gets the body to fight off infection for several years. For PrEP, one takes a pill every day by mouth. The pill that has been proven to be safe, and with efficacy to help block HIV infection is called Truvada $(3,4)$. Truvada is a combination of two drugs (tenofovir and emtricitabine). Importantly, if PrEP is taken daily, the presence of the medicine in the bloodstream often stop HIV from taking hold and spreading in the body system of the user $(3,4)$. Unfortunately, if PrEP is not used every day as required, there may not be enough medicine in the bloodstream to block the HIV virus, but when taken every day and consistently, PrEP is found to be safe and highly effective in preventing HIV infection among users $(3,4)$. Significantly, PrEP reaches maximum protection from HIV for receptive anal sex at about seven days of daily use, for receptive vaginal sex and injection drug use; PrEP reaches maximum protection at about twenty days of daily use $(3,4)$. Although, no data are yet available about how long PrEP takes to reach maximum protection for insertive anal or insertive vaginal sex (3).

\subsection{The need for the use of PrEP in the prevention of HIV/AIDS in Sub-Saharan Africa}

Africa is the most affected continent with HIV infection, with 25.7 million individuals living with HIV in 2017 (2). The African continent likewise represents more than $66 \%$ of the worldwide aggregate of new HIV infections (2). Different preventive measures for the prevention of HIV/AIDS, for example, the use of condoms, has been employed over the years, yet, the number of infection cases is still rising in African countries. Fortunately, through continuous and assiduous efforts of researchers in the field of HIV/AIDS prevention, they have provided the world with a new preventive measure, which is pre-exposure prophylaxis (PrEP). Clinical trials have found that PrEP is highly effective in reducing the risk of HIV infection across types of exposures (6). Also, randomized clinical trials have demonstrated the efficacy of antiretroviral pre-exposure prophylaxis (PrEP) in preventing HIV infection among men who have sex with 


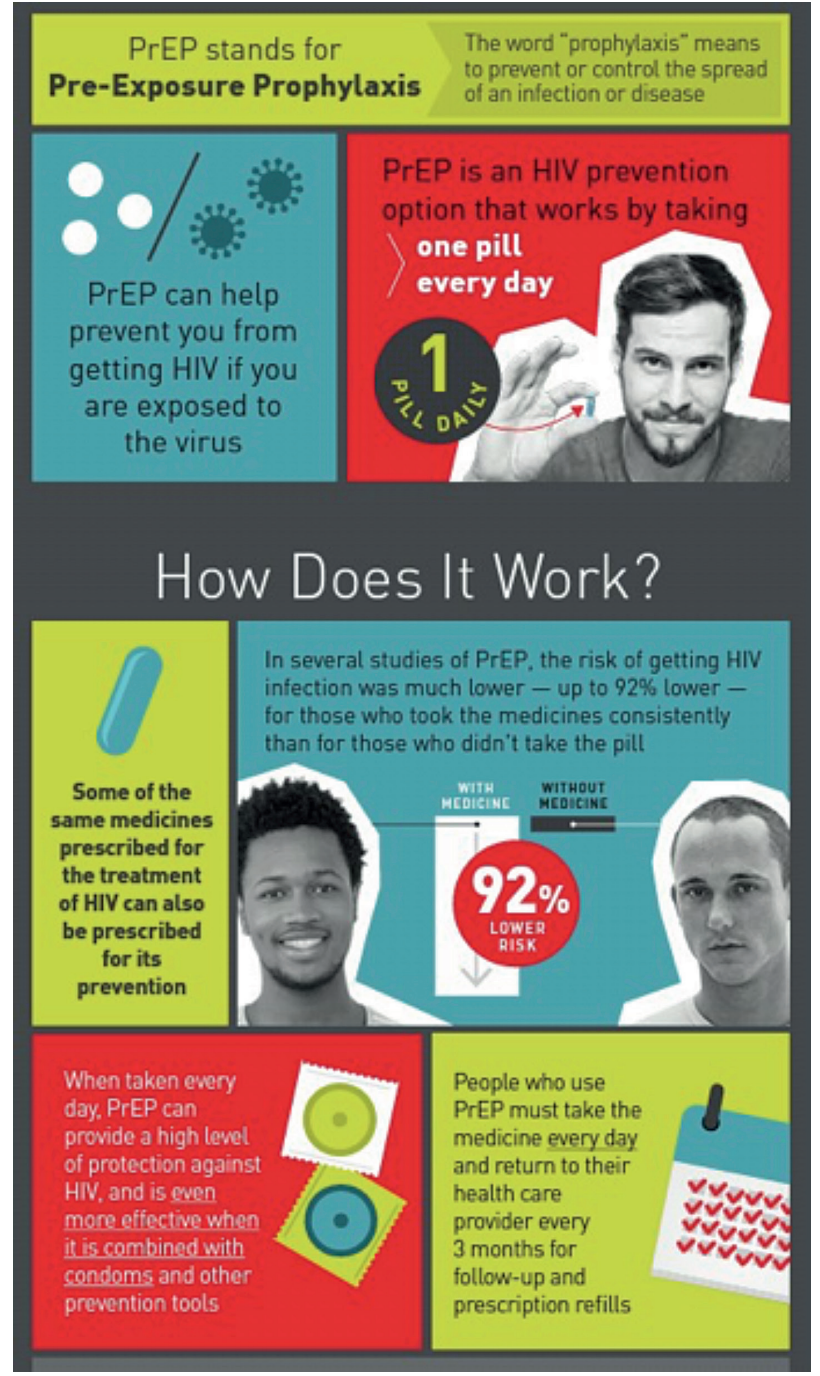

Figure 3. Pre-exposure prophylaxis (PrEP) at a glance Picture Source: Centers for disease control and prevention (CDC) (2018).

men (MSM) (7). According to a cross sectional study, preexposure prophylaxis (PrEP) can reduce HIV transmission risk for many gay, bisexual and other men who have sex with men (8). Furthermore, results from a comparative pre-exposure prophylaxis efficacy study against HIV-1 vaginal transmission revealed that daily oral antiretroviral (ARV) drugs for pre-exposure prophylaxis (PrEP) has proven efficacy for diverse groups of high-risk individuals (9). Notably, oral pre-exposure prophylaxis (PrEP) is an effective strategy that should be employed to reduce the risk of HIV transmission in high risk individuals. However, the effectiveness of oral pre-exposure prophylaxis is highly dependent on the users' adherence. Also, oral pre-exposure prophylaxis should be delivered within a holistic intervention (10). For a higher chance of prevention of HIV infec- tion, recent research data suggests that PrEP, combined with other prevention strategies, holds promise in helping to curtail the HIV epidemic, as a randomized, controlled trial of a topical pericoital antiretroviral microbicide gel decreased HIV incidence among at-risk heterosexual South African women (11). The rate of HIV infection can be reduced across the world, and to achieve the 90-90-90 goals set by UNAIDS, the number of new HIV infections needs to decrease at least to approximately 500,000 by 2020. One of the major prerequisites to achieve this goal is pre-exposure prophylaxis (PrEP) (12).

\subsection{Update on the implementation of PrEP for the prevention of HIV/AIDs in Sub-Saharan Africa}

Pilot PrEP projects have been underway in some African countries for several years, but it has only been since late 2017 that some African countries, notably Kenya and South Africa, and also Swaziland, have started serious PrEP availability programmes for wider populations who are at risk of HIV infection. For example, in South Africa, approximately 25,000 to 30,000 people have started taking PrEP, Kenya has initiated PrEP in about 25,000 people, Zimbabwe in about 5,000, and 2,250 people in Swaziland have been assessed for PrEP, and if all of them start it, this will be about three times the number per head of the population compared with Kenya (13). Furthermore, Lesotho, Zambia, and Senegal have also started PrEP programmes, either among targeted populations such as sex workers, or among the general population at-risk (13). Unfortunately, the number of African countries that have started PrEP programmes is far lesser compared to fifty-four countries in the continent. To achieve the $90-90-90$ goals set by UNAIDS to help end the AIDS epidemic, more African countries should be encouraged and assisted with the personnel, materials and funds by the World Health Organization (WHO), and other major health international agencies to set up, and start PrEP programmes in the coming years, since the African continent has the highest number of HIV infections and deaths from HIV/AIDS.

\subsection{Barriers to the implementation of PrEP for the prevention of HIV/AIDs in Sub-Saharan Africa}

Socio-economic factors and poor governmental policy remain major barriers to widespread implementation of pre-exposure prophylaxis in Africa. Although, other probable factors hindering the implementation of PrEP 
for the prevention of HIV/AIDs in Sub-Saharan Africa are discussed as follows:

\section{Experience of side effects}

- In some African countries that have started the PrEP programmes, experience of side effects was a major factor for the discontinuance of the treatment in Kenya and South Africa. For example, in South Africa, among those who had stopped PrEP, side effects were by far the most common reason to stop among FSWs and MSM, as three-quarters of FSWs and $87 \%$ of MSM said that side effects including gastrointestinal upset, nausea, dizziness, running stomach, darkening of the skin, and headaches were their main reason for stopping PrEP. For instance, one PrEP taker stated that "I took the bottle halfway due to the side effects."(13).

\section{Fears}

- Another factor impeding the use of PrEP for the prevention of HIV/AIDs in Sub-Saharan Africa among users that have started the programme in African countries is imaginary beliefs and phobia among the populace. For instance, people feared that PrEP intake might cause impotence, sterility or being used as a specimen of HIV control measures.

\section{Stigmatization}

- Stigmatization has been a long-lasting factor impeding the eradication of HIV/AIDS epidemic in Africa, and now, it is also a concern for the administration of PrEP. This is due to social disapproval among the populace. For example, one woman recounted that "When I informed my husband, he refused and told me that he should not find me using it. So, I started taking the drug in secret. When he came to know about it, when he saw that bottle he beat me to an extent of breaking my nose" (13).

\section{Proximity to PrEP centers}

- Another major challenge for the usage of PrEP for the prevention of HIV/AIDs in Sub-Saharan Africa is the proximity to places where the PrEP centers are located. Since there are few PrEP centers around, people have difficulty in transporting themselves to locations where these centers are located.

\section{Structural barriers}

- There are deficiency and depleted health buildings in many African countries, bad road network hinders people from readily accessing hospital facilities, and PrEP centers. This may be a hindrance to the PrEP programmes as users of PrEP needs to take the drug daily, and frequent medical checkups are required to check the progress of the drug, and to look for signs and symptoms of side effects.

\section{Funding}

- Many of the African countries are running a budget deficit, and as such, the budget allocated for health is so small that it is not even enough for the overall health sector. The setting up of the PrEP programme requires substantial amount of money to buy the drugs and other materials used for PrEP. In a situation where funds are not available, most of the African countries find it difficult to start the PrEP programme, unless there is assistance from international health agencies.

\section{Conclusions}

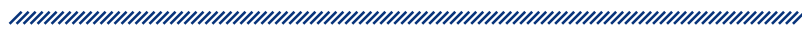

Studies have affirmed that PrEP is highly effective for preventing HIV, as daily PrEP reduces the risk of getting HIV infection from sex by more than $90 \%$, among people who inject drugs it reduces the risk by more than $70 \%$, the risk of getting HIV from sex can be lower if PrEP is combined with condoms and other prevention methods (3). Sub-Saharan Africa continues to be the continent with the highest cases of infections and deaths from HIV/AIDS even after the implementation of previous HIV/AIDS prevention methods. To achieve the 90-90-90 goals set by UNAIDS to help end the AIDS epidemic in the world, this review concluded that PrEP offers a new way of prevention, and its implementation across all African countries is urgently needed for the prevention of HIV/AIDs in Sub-Saharan Africa.

\section{Recommendations}

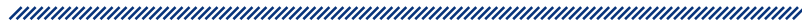

Consequent upon the review of literature, the following recommendations are proffered:

1. There should be the political need and will on the part of the government to create a legal basis, and the requirements to invest massively in the health sector and the PrEP programme. This could be achieved by making sure that the health budget is increased, and expended in the right way. 
2. PrEP users should be told about side effects in pre-PrEP counseling sessions, and how to manage those side effects should be clearly explained to the users.

3. Massive sensitization should be organized to enlighten the public about the importance of PrEP, and to allay fears the populace might have towards the programme in countries where the PrEP programmes have begun.

4. African countries should be encouraged and assisted with the personnel, materials and funds to buy PrEP drugs by the WHO, and other major health international agencies to set up, and start PrEP programmes

5. As a matter of urgency, PrEP programmes should be started in all African countries with the highest number of HIV/AIDS infections and deaths, e.g., Lesotho, Botswana, Namibia, Zimbabwe, Zambia, Mozambique, Malawi, Uganda, Nigeria, and so on, to achieve the $90-90-90$ goals set by UNAIDS to help end the AIDS epidemic in the world.

\section{Acknowledgments}

Great thanks are given to unknown reviewers for valuable comments. Furthermore, I thank all my colleagues working assiduously on the epidemiology and prevention of HIV/AIDS who over the time have contributed to the ideas discussed in this article.

\section{Conflict of interest}

"

The author has no conflicts of interest to declare.

\section{Funding}

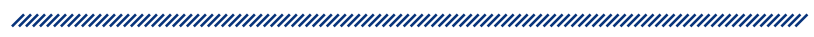

Self-funded.

\section{References}

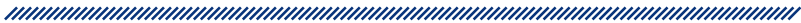

1. Krämer A, Kretzschmar M, Krickeberg K. Modern infectious disease epidemiology concepts, methods, mathematical models, and public health.(Online-Ausg. ed.) New York: Springer. 2010, p. 88.

2. World Health Organization. HIV/AIDS key facts. http:// www.who.int/en/news-room/fact-sheets/detail/hivaids. 2018.

3. Centers for disease control and prevention. PrEP. https:// www.cdc.gov/hiv/basics/prep.html\#. 2019.

4. Duwal S, Dickinson L, Khoo S, et al. Mechanistic framework predicts drug-class specific utility of antiretrovirals for HIV prophylaxis. PLoS Comput Biol. 2019; 15(1):e1006740. doi: 10.1371/journal.pcbi.1006740.

5. Eakle R, Venter F, Rees H. Retrovirology. 2018; 15(1):29. doi:10.1186/s12977-018-0408-3.

6. O'Malley G, Barnabee G, Mugwanya K. Scaling-up PrEP Delivery in Sub- Saharan Africa: What Can We Learn from the Scale-up of ART?. Curr HIV/AIDS Rep. 2019. doi: 10.1007/s11904-019-00437-6

7. Wheeler DP, Fields SD, Beauchamp G, et al. Pre-exposure prophylaxis initiation and adherence among Black men who have sex with men (MSM) in three US cities: results from the HPTN 073 study. J Int AIDS Soc. 2019; 22(2):e25223. doi:10.1002/jia2.25223.

8. John SA, Parsons JT, Rendina HJ, et al. Club drug users had higher odds of reporting a bacterial STI compared with non-club drug users: results from a cross-sectional analysis of gay and bisexual men on HIV pre-exposure prophylaxis. Sex Transm Infect. 2018. pii:sextrans-2018-053591. doi: 10.1136/sextrans-2018-053591.

9. Mandal S, Kang G, Prathipati PK, et al. Nano encapsulation introduces long-acting phenomenon to tenofovir alafenamide and emtricitabine drug combination: A comparative pre-exposure prophylaxis efficacy study against HIV-1 vaginal transmission. J Control Release. 2019; 294:216-225. doi: 10.1016/j.jconrel.2018.12.027.

10. Sidebottom D, Ekström AM, Strömdahl S. A systematic review of adherence to oral pre-exposure prophylaxis for HIV - how can we improve uptake and adherence?. BMC Infect Dis. 2018; 18(1):581. doi:10.1186/s12879-018-3463-4.

11. Krakower D, Mayer KH. What primary care providers need to know about pre-exposure prophylaxis for HIV prevention: a narrative review. Ann Intern Med. 2012; 157(7):490-7. Doihttps://annals.org/aim/fullarticle/1363525/what-primary-care-providers-need-know-about-preexposureprophylaxis-hiv.

12. Duwal S, Dickinson L, Khoo S, et al. Hybrid stochastic framework predicts efficacy of prophylaxis against HIV: An example with different dolutegravir prophylaxis schemes. PLoS Comput Biol. 2018; 14(6):e1006155. doi: 10.1371/ journal.pcbi.1006155.

13. Gus C. (2018). PrEP spreads across Africa - slowly. http:// www.aidsmap.com/PrEP-spreads-across-Africa-slowly/ page/3318441/. 


\section{HITNA POTREBA ZA KORIŠTENJEM PREEKSPOZICIJSKE PROFILAKSE (PrEP) U PREVENCIJI HIV/AIDS-a U SUBSAHARSKOJ AFRICI}

1 Israel Oluwasegun Ayenigbara

1 Department of Human Kinetics and Health Education, Univerity of Ibadan, Ibadan, Nigeria

\section{Sažetak}

Virus humane imunodeficijencije (HIV) je infekcija koja je nastala prije nekoliko desetljeća; proširila se afričkim zemljama kasnih sedamdesetih godina i trenutno je endemska bolest širom svijeta. HIV predstavlja veliki javnozdravstveni problem u cijelom svijetu jer je odnio više od 35 milijuna života. Krajem 2017. Godine bilo je oko 36,9 milijuna osoba koje žive s HIV-om, a subsaharska Afrika je i dalje najviše pogođena HIV infekcijom s 1 na 25 odraslih osoba(4,1\%) koji žive s virusom, što čini 70\% ljudi koji žive s HIV-om širom svijeta. Nažalost, subsaharska Afrika je i dalje kontinent s najvišim brojem infekcija i smrti od HIV/AIDS-a, čak i nakon provedbe različitih metoda prevencije. Srećom, preekspozicijska profilaksa (PrEP) svijetu nudi novi način ograničavanja epidemije HIV/AIDS-a, budući da je PrEP visoko učinkovit u sprječavanju HIV-a ako se koristikako je propisano. U ovom se radu raspravlja o hitnoj potrebi korištenja PrEP-a u prevenciji HIV/AIDS-a u subsaharskoj Africi. To je pregledni rad u kojem se raspravlja o značenju PrEP-a, identificirani su ljudi kojima je potreban PrEP, istaknuta je svrha primjene PrEP-a za prevenciju HIV/AIDS-a u subsaharskoj Africi te su također identificirane moguće prepreke za uspješnu provedbu
PrEP-a za prevenciju HIV/AIDS-a u subsaharskoj Africi. Zaključeno je da je za postizanje ciljeva 90-90-90 koje je UNAIDS postavio kako bi se okončala epidemija AIDS-a u svijetu, PrEP nudi novi način prevencije HIV-a, a njezina primjena u svim afričkim zemljama hitno je potrebna za prevenciju HIV/AIDS-a u subsaharskoj Africi.

Ključne riječi: HIV/AIDS, preekspozicijska profilaksa (PrEP), subsaharska Afrika, prevencija 